\title{
Pengaruh Promosi dan Saluran Distribusi Terhadap Volume Penjualan Sosis BE MART Cabang Bima.
}

\author{
Jainuddin, Sri Ernawati \\ Sekolah Tinggi Ilmu Ekonomi Bima
}

Email: sriernawati.stiebima@gmail.com

Naskah diterima 1 Maret 2020, Revisi 20 Maret 2020, Terbit 19 April 2020

\begin{abstract}
Abstrak
DOI: doi.org/10.21107/pamator.v13i1.6917

Persaingan bisnis yang ketat menuntut setiap perusahaan untuk saling berkompetisi, sehingga promosi dan saluran distribusi yang efektifitas dan efisiensi dalam pendayagunaan sumber daya yang dimiliki harus dilakukan untuk meningkatkan volume penjualan. Tujuan dari penelitian ini adalah untuk mengetahui pengaruh promosi dan saluran distribusi terhadap volume penjualan pada Sosis BE MART Cabang Bima. Penelitian ini mengambil sampel 96 dengan teknik purposive sampling. Instrumen penelitian menggunakan kuesioner dengan skala likert, dimana kuesioner dibagikan kepada konsumen yang perna membeli produk sosis BE MART. Metode analisis data yang di gunakan yaitu analisis regresi linier berganda dengan pengolahan data menggunakan SPSS 20.00. Hasil penelitian menyatakan bahwa promosi tidak berpengaruh terhadap volume penjualan dan saluran distribusi berpengaruh terhadap volume penjualan BE MART Cabang Bima.
\end{abstract}

Kata kunci : promosi, saluran distribusi,volume penjualan

\section{PENDAHULUAN}

Pemasaran pada perusahaan merupakan fungsi yang menentukan bagi keberhasilan perusahaan untuk memperoleh laba yang akan berdampak pada kelangsungan hidup perusahaan. Sementara itu pertumbuhan ekonomi Indonesia yang semakin meningkat menyebabkan permintaan terhadap produk makanan juga semakin meningkat, sehingga semakin banyak pengusaha mendirikan perusahaan makanan yang menyebabkan meningkatnya persaingan antara sesama perusahaan untuk merebut pangsa pasar. Hal ini karena konsumen mempunyai kebebasan yang lebih luas untuk memilih (Kusuma et.al, 2015).

Promosi adalah suatu bentuk aktivitas pemasaran yang berusaha untuk menyebarkan informasi, mempengaruhi/ membujuk dan atau mengingatkan pasar sasaran atas perusahaan dan produknya agar bersedia menerima, membeli dan loyal pada produk yang ditawarkan perusahaan yang bersangkutan (Shinta, 2011). Selain promosi, perusahaan perlu melakukan upaya saluran distribusi agar produk perusahaan bisa tersebar secara luas dan merata. Menurut Tjiptono dan Chandra (2012), saluran distribusi merupakan serangkaian partisipan organisasional yang melakukan semua fungsi yang dibutuhkan untuk menyampaikan produk/jasa dari penjual ke konsumen akhir

Strategi promosi yang dilakukan oleh perusahaan dipengaruhi juga oleh jenis produknya. Strategi yang diambil dalam mempromosikan barang perusahaan harus menjual kepada pembeli dengan mempromosikan produk tersebut secara umum pada tahap pertumbuhan, kedewasaan dan periklanan. Sedangkan pada tahap penurunan, perusahaan harus membuat produk baru atau produk yang lebih menarik. Dalam pendistribusian suatu produk, perencanaan sangat mutlak diperlukan selain untuk mempermudah penyampaian barang dari produsen ke konsuiten akhir, juga untuk menunjang keunggulan daya saing suatu produk. Perencanaan perlu senantiasa ditajamkan dalam strategi pendistribusian suatu produk perusahaan agar tujuan distribusi dapat terwujud dengan tepat pada sasarannya (Ada et.al, 2012).

Penjualan adalah interaksi antara individu saling bertemu muka yang ditujukan untuk menciptakan, memperbaiki, menguasai atau mempertahankan hubungan pertukaran sehingga menguntungkan bagi pihak lain, (Swastha, 2010). Setiap perusahaan dapat 
meningkatkan penjualan produknya dengan mengunakan sistem pemasaran yang efektif dengan mengunakan strategi-strategi khusus dalam meningkatkan pasar konsumen yang ada. Dengan adanya strategi pemasaran yang tepat dari perusahaan jelas dapat mempengaruhi konsumen untuk tertarik dan membeli hasil produk yang di tawarkan oleh perusahaan tersebut (Paputungan et.al, 2017).

Seperti penelitian yang dilakukan Ramadhan dan Afandi (2017), dimana secara simultan variabel promosi dan saluran distribusi secara signifikan memiliki pengaruh positif dan signifikan terhadap volume penjualan. Saluran distribusi yang luas dapat manambah peluang pasar, untuk bisa mendapatkan pelanggan perusahaan menggunakan promosi yang baik agar dapat memengaruhi pelanggan untuk membeli produk perusahaan sehingga tujuan untuk memperoleh laba maksimun bisa tercapai dan membuat volume penjualan perusahaan meningkat.

Fakta empiris yang terjadi dari hasil observasi yang dilakukan peneliti diperoleh data dimana berkaitan dengan perusahaan yang di teliti dimana masih di katakan perusahaan baru, maka produk yang akan di tawarkan harus benar-benar menarik dan bisa memuaskan konsumen. Agar bisa membuat konsumen merasa puas dengan produk yang di tawarkan oleh perusahaan agar produk yang di tawarkan kepada konsumen bisa dengan cepat di kenal luas oleh calon konsumen lainnya. Begitupun dengan saluran distribusi yang masih minim di perusahaan tersebut, karena belum begitu di kenal luas oleh masyarakat, saat ini perusahaan masih mendistribusikan prodaknya di kios-kios maupun toko terdekat, sehingga pasar sosis BE MART masih sebatas wilayah Bolo tepatnya di wilayah Sila Rato, Kabupaten Bima.

\section{METODOLOGI}

Penelitian ini menggunakan pendekatan kuantitatif dengan metode survey. Sedangkan jenis penelitian dikategorikan sebagai penelitian kausal. Menurut Husein (2013) desain kausal digunakan untuk mengukur kuat hubungan dan pengaruh antara variabel independent (promosi dan saluran distribusi) terhadap variabel dependent (volume penjualan). Populasi dalam penelitian ini adalah konsumen yang perna membeli sosis BE MART. Teknik pengambilan sampel yang digunakan dalam penelitian ini adalah purposive sampling yaitu teknik pengambilan sampel dari populasi berdasarkan kriteria tertentu (Hartono, 2010). Jumlah sampel dalam yang diambil dalam penelitian ini adalah 96 responden. Instrumen penelitain menggunakan kuesioner dengan skala Likert. Analisis data menggunakan regresi linear berganda dengan persamaa sebagai berikut:

$$
Y=a+\beta 1 X 1+\beta 2 X 2+e
$$

Dimana :

$$
\begin{array}{ll}
\mathrm{Y} & =\text { Volume Penjualan } \\
\mathrm{a} & =\text { Konstanta } \\
\beta 1 \beta 2 & =\text { Koefisien regresi } \\
\mathrm{X} 1 & =\text { Promosi } \\
\mathrm{X} 2 & =\text { Saluran Distribusi } \\
\mathrm{e} & =\text { Error }
\end{array}
$$

\section{HASIL DAN PEMBAHASAN}

\section{Karakteristik Responden}

Dari 96 kuesioner yang disampaikan kepada responden semuanya mengembalikan semua karena teknik yang peneliti gunakan yaitu purposive Sampling, jadi peneliti turun melakukan penelitian langsung menyerahkan kuesioner kepada masyarakat atau agen yang membeli. Gambaran umum responden dalam penelitian ini dilihat dari karakteristik yang meliputi jenis kelamin, pendidikan pekerjaan. Gambaran umum mengenai profil responden dalam penelitian ini dapat dilihat dalam Tabel 1.

Tabel 1. Karakteristik Responden

\begin{tabular}{llcc}
\hline Karakteristik & \multicolumn{1}{c}{ Kriteria } & $\begin{array}{c}\text { Jumlah } \\
\text { responden }\end{array}$ & Persentase \\
\hline Jenis & Perempuan & 64 & 66,66 \\
Kelamin & Laki-laki & 32 & 33,33 \\
Pendidikan & 9 & 9,37 \\
& Strata dua (S2) & 17 & 17,70 \\
& Strata Satu (S1) & 25 & 26,04 \\
& Ahli Madya (D3) & 45 & 46,87 \\
Pekerjaan & SMA & 6 & 6,25 \\
& PNS & 18 & 18,75 \\
& Pegawai Swasta & 20 & 20,83 \\
& Wirausaha & 29 & 30,20 \\
& Pelajar/Mahasiswa & 23 & 23,95 \\
Umur & lain-lain & 76 & 79,16 \\
& 17-25 & 13 & 13,54 \\
& 26-35 & 7 & 7,29 \\
\hline
\end{tabular}

Berdasarkan Tabel 1 dapat diketahui mayoritas responden dari yaitu sebesar $66,66 \%$ perempuan. Pendidikan mayoritas dari SMA sebesar 46,87\%. Mayoritas 
pekerjaan dari Pelajar/mahasiswa sebesar $30,20 \%$. dan umur dominasi dari 17-25 tahun sebesar $79,16 \%$.

\section{Uji Regresi Linear Berganda}

Analisis pada penelitian ini menggunakan analisis regresi linier berganda. Dalam uji regresi ini dilaksanakan guna mengetahui arah hubungan apakah positif atau negatif antara variabel independent dengan variabel dependent. Berikut hasil perhitungan regresi linier berganda dengan menggunakan bantuan program SPSS 20.00.

Tabel 2. Hasil Uji Regresi Linear Berganda

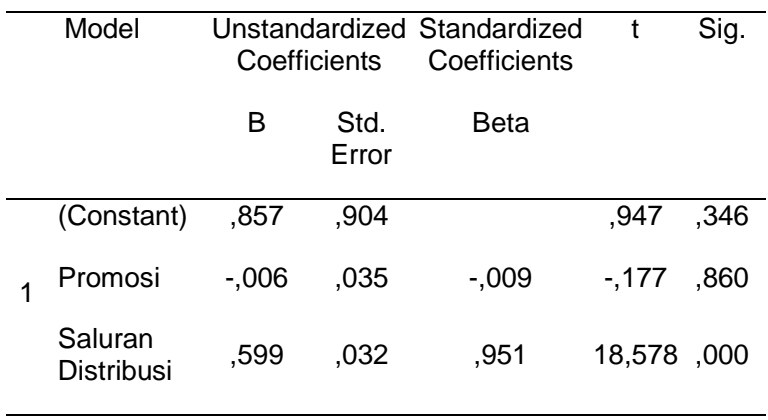

Dari data tabel 2 dapat dibuat persamaan $Y=0,857-0,006 X_{1}+0,599 X_{2}$. Berdasarkan persamaan regresi linear berganda tersebut diatas maka dapat diinterprestasikan sebagai berikut ini :

a. Nilai konstanta bernilai positif sebesar 0,856 hal ini menunjukkan apabila promosi dan saluran distribusi konstan maka volume penjualan mengalami peningkatan sebesar 0,856.

b. Koefisien regresi variabel promosi $X_{1}$ bernilai negatif sebesar $-0,006$ hal ini menunjukkan bahwa apabila promosi semakin turun dengan asumsi variabel lain konstan, maka hal tersebut dapat menurunkan volume penjualan sebesar 0,006 .

c. Koefisien regresi variabel Saluran distribusi $\mathrm{X}_{2}$ bernilai positif sebesar 0,599, hal ini menunjukkan apabila variabel Saluran distribusi semakin baik dengan asumsi variabel lain konstan, maka hal tersebut dapat meningkatkan volume penjualan sebesar 0,599.

\section{Uii-t (Uii Parsial)}

Tabel 3. Hasil Uji-t

\begin{tabular}{|c|c|c|c|c|c|c|}
\hline & Model & $\begin{array}{r}\text { Unstan } \\
\text { Coef }\end{array}$ & $\begin{array}{l}\text { ardized } \\
\text { ients }\end{array}$ & $\begin{array}{l}\text { Standardized } \\
\text { Coefficients }\end{array}$ & $t$ & Sig. \\
\hline & & B & $\begin{array}{l}\text { Std. } \\
\text { Error }\end{array}$ & Beta & & \\
\hline & (Constant) & ,857 & ,904 & & ,947 & ,346 \\
\hline 1 & Promosi &,- 006 &, 035 &,- 009 &,- 177 & ,860 \\
\hline & $\begin{array}{l}\text { Saluran } \\
\text { Distribusi }\end{array}$ & -599 & ,032 & 951 & 18,578 & , 000 \\
\hline
\end{tabular}

Pengaruh promosi terhadap volume penjualan

Hasil statistik uji-t untuk variabel promosi diperoleh nilai $t_{\text {hitung }}$ sebesar $-0,177$ dengan nilai $t_{\text {tabel }}$ sebesar $1,985 \quad(-0,177<1,985)$ dengan nilai signifikansi sebesar 0,0860 lebih besar dari $0,05(0,0860>0,05)$, dan koefisien regresi mempunyai nilai negatif sebesar -0,006; maka hipotesis yang menyatakan bahwa promosi berpengaruh terhadap volume penjualan Sosis BE MART Cabang Bima tidak terbukti.

Promosi merupakan kegiatan pemasaran yang bertujuan untuk menginformasikan dan mendorong permintaan terhadap produk, jasa dan ide dari perusahaan dengan cara mempengaruhi para pelanggan sasaran agar mau membeli barang dan jasa yang dihasilkan oleh perusahaan. Jika suatu barang/jasa tidak dipromosikan, maka produk yang dihasilkan oleh perusahaan tidak akan dikenal oleh masyarakat luas. Promosi berhubungan erat dengan volume penjualan, karena apabila volume penjualan meningkat, maka secara tidak langsung pelanggan akan mempromosikan atau merekomendasikan produk tersebut kepada orang lain.

\section{Pengaruh saluran distribusi terhadap volume penjualan}

Hasil statistik uji-t untuk variabel saluran distribusi diperoleh nilai $t_{\text {hitung }}$ sebesar 18,578 dengan nilai $t_{\text {tabel }}$ sebesar 1,985 $(18,578>1,985)$ dengan nilai signifikansi sebesar 0,000 lebih besar dari 0,05 $(0,000<0,05)$, dan koefisien regresi mempunyai nilai positif sebesar 0,599; maka hipotesis yang menyatakan bahwa saluran distribusi berpengaruh terhadap volume penjualan Sosis BE MART Cabang Bima terbukti. 
Saluran distribusi mempunyai hubungan erat dengan volume penjualan. Saluran distribusi yang maksimal dari para penyedia produk akan meningkatkan volume penjualan. Saluran distribusi memberikan suatu dorongan kepada pelanggan untuk menjalin hubungan yang kuat dengan perusahaan, seperti dikutip dari pernyataan yang menyatakan bahwa aluran distribusi pada dasarnya merupakan suatu cara menyusun pekerjaan yang perlu dilaksanakan untuk proses pemindahan barang-barang dari produsen ke konsumen yang tujuannya untuk menjembatani aneka jurang yang dapat memisahkan barangbarang dan jasa-jasa dari orang-orang yang dapat menggunakannya. Tujuan dari kegiatan saluran distribusi barang yang dijalankan oleh perusahaan tidak lain untuk memberi kemudahan kepada konsumen sehingga konsumen dapat dengan mudah memenuhi kebutuhannya (Djaharuddin, 2017).

\section{Uii Determinasi}

Berdasarkan kontribusi yang diberikan dari variabel iklan, kepercayaan merek dan citra merek berpengaruh terhadap minat beli konsumen dan dapat dilihat dari koefisien determinasinya. Perolehan nilai determinasi $\left(R^{2}\right)$ dapat dilihat pada table dibawah ini : Tabel 4. Hasil Uji Determinasi $\left(R^{2}\right)$ Model R R Square Adjusted R Std. Error of $1 \quad, 944^{\mathrm{a}} \quad, 891 \quad, 889 \quad 1,834$ a. Predictors: (Constant), Promosi dan Saluran Distribusi b. Dependen Variable: Volume Penjualan

Berdasarkan hasil uji determinasi tabel tersebut diatas, maka dapat dijelaskan bahwa besarnya koefisien determinasi $\left(R^{2}\right)$ adalah 0,891 angka koefisien determinasi menyatakan bahwa variabel promosi dan saluran distribusi hanya dapat menjelaskan atau memberikan kontribusi atas variasi perubahan volume penjualan sebesar $89,1 \%$ sedangkan sisanya $10,9 \%$ dipengaruhi oleh variabel-variabel lain yang tidak di libatkan dalam penelitian ini.

\section{KESIMPULAN}

Kesimpulan yang bisa diambil dari hasil pembahasan dalam penelitian ini adalah promosi tidak berpengaruh terhadap volume penjualan dan saluran distribusi berpengaruh terhadap volume penjualan. Ada beberapa saran yang bisa diberikan kepada perusahaan BE MART Cabang Bima terkait dengan peningkatan volume penjualan seperti (1) Memperluas jaringan distribusi ke daerah sekitar Kabupaten Bima seperti Kota Bima dan Kabupaten Dompu; (2) Meningkatkan promosi di sosial media dan menjadi sponsor untuk acara yang berkaitan dengan anak-anak, karena sosis sangat digemari oleh anak-anak.

\section{DAFTAR PUSTAKA}

Agustina, S. 2011. Manajemen Pemasaran. UB Press. Malang.

Desiastuty, P., Johny, T.R \& Olivia, W. 2017. Pengaruh Promosi Terhadap Peningkatan Penjualan PT Columbia Kotamobagu. Jurnal Administrasi Bisnis. Vol 5. No 4

Dharmawaty, D. 2017. Pengaruh Saluran Distribusi Terhadap Volume Penjualan Pada UD. Timur Terang Makassar. Jurnal Ekonomi dan Bisnis Kontemporer. Vol 3. No 2.

Hartono, J. 2010. Metodologi Penelitian Bisnis: Salah Kaprah dan PengalamanPengalaman. Edisi Pertama. BPFE. Yogyakarta

Jeffrei, K.A., Karim, B \& Bagus, R.Q. 2015. Pengaruh Bauran Promosi Terhadap Volume Penjualan Holcim Solusi Rumah Bintang Jaya di Jember. Jurnal Manajemen dan Bisnis Indonesia. Vol 1 No 2. $162-181$ pp.

Panji, R.A \& Yosi, A. 2017. Pengaruh Promosi dan Saluran Distribusi Terhadap Volume Penjualan Pada PT Rajawalinusindo Cabang Malang. Jurnal Aplikasi Bisnis. Vol 3 No 2.

Sabinen, A., Senen, M \& Fitri, F. 2012. Pengaruh Promosi dan Distribusi Terhadap Volume Penjualan (Studi Kausal PT Nikatsu Electric WorksBandung). Jurnal Manajerial Vol 10 No 1. 
Swastha, B. 2010. Manajemen Penjualan: Tjiptono \& Gregorius, C. 2012. Pemasaran Pelaksanaan Penjualan. BPFE. Strategik. Edisi Kedua. CV Andi Offset. Yogyakarta Jogjakarta.

Umar, H. 2015. Metodologi Penelitian : Aplikasi dalam Pemasaran. Gramedia Pustaka Utama. Jakarta 